\title{
豪雨防災情報に対する \\ インターネット利用者の認識 \\ AN ANALYSIS OF UNDERSTANDING OF INTERNET USERS FOR HEAVY RAINFALL DISASTER INFORMATION
}

\author{
牛山素行 1 ・吉田亜里紗 2 ・國分和香那 2 \\ Motoyuki USHIYAMA, Arisa YOSHIDA and Wakana KOKUBU \\ 1正会員 博(農) ・ 博(工) 岩手県立大学准教授 (T⿳020-0193 岩手県岩手郡滝沢村滝沢字巣子152-52) \\ 2非会員 岩手県立大学学生 総合政策学部 ( T020-0193 岩手県岩手郡滝沢村滝沢字巣子152-52)
}

\begin{abstract}
Understanding of Internet users for real-time precipitation or water level information was researched based on Internet questionary survey in February 2007. The percentage of recognition for "River Disaster Prevention Information", administrated by River Bureau, was only 4.7 \%. It is hardly different from the result of similar survey in 2004. Even if real-time heavy rainfall disaster information Web pages were introduced to respondents, the answer with a clear use intention was about $10 \%$. The use intention of cellular phone web pages was still lower. "The television is more useful for an emergency" etc. was mentioned as the reason. It is possible that even if well-known to these pages, many people may not use. There is no doubt about public presentation of information is important. However, it is also important to develop simple information communication system to general public for heavy rainfall disaster prevention.
\end{abstract}

Key Words : real-time precipitation or water level information, Internet questionary survey, use intention, heavy rainfall disaster prevention.

\section{1. はじめに}

近年，気象庁，国土交通省，都道府県などにより，雨 量, 水位をはじめとしたリアルタイム情報の公開が, Webなどを通じて積極的に行われている．これらの情報 整備では, リアルタイム観測情報を活用して，災害から の避難や被害軽減がなされることが期待されていると考 えられる，そうした情報を害際に被害軽減に役立てるた めには，まず利用者に認知・利用してもらう必要がある が，その実態についての調査結果はあまり見られない. これまでに，情報提供者側による「情報に対する満足 度」に関する調查例はあるが1)，「提供されている情報 のことをある程度知っており，その情報を積極的に使い たいと考え, 使い勝手についての意見を持っている」と いった，どちらかというと積極的な情報利用者モデルが 前提となっているようである. しかし，災害後の被災地 域の調査例では2)，すでに公開されているはずの「降雨 量や水位の変化図やグラフ」や，「数時間先の降雨量や 河川水位の予測值」の整備が今後必要であると回答する 人が多数現れるといった現実もある. 既に提供されてい
る情報がどの程度認知され，それらの情報に対する利用 意向がどの程度あるのか，情報の整備実態に応じた実証 的研究を重祆る必要がある.

筆者は以前から，豪雨災害の被災者や，市町村防災担 当者を対象にリアルタイム雨量・水位情報等の認知, 利 用実態, 利用意向についての調査を行っており, これら の情報があまり認知されておらず，認知されていても必 ずしも積極的に利用されていないことを示唆してきだ). 本研究では, インターネット利用に比較的習熟している 被験者を対象とし, 近年のインターネット利用者のリア ルタイム雨量・水位情報等に対する認知状況や利用意向 について調査し, 今後のリアルタイム防災情報のあり方 について考える.

\section{2. 調査手法}

調查は，インターネット上のリサーチサービスである NTTレゾナント社のgooリサーチを用いて行った。 これは, 登録されているモニターにアンケート調査依頼メールを 配信し，調查に応じたモニターがwebを通じて回答し， 


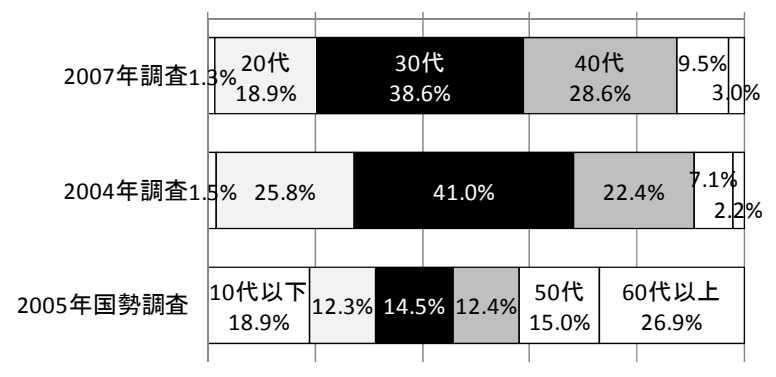

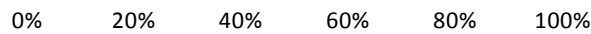

図-1＼cjkstart回答者の年代構成
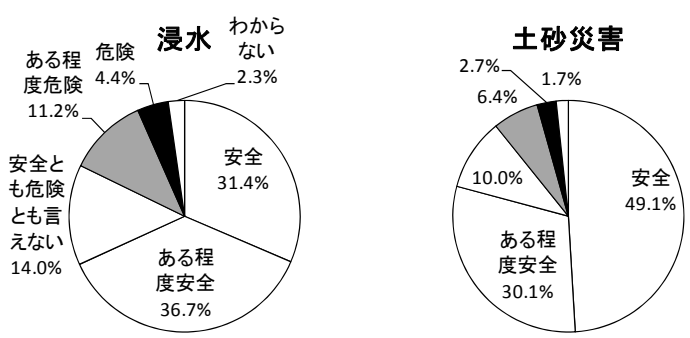

図-2＼cjkstart豪雨災害にに対する認識(2007年調査)

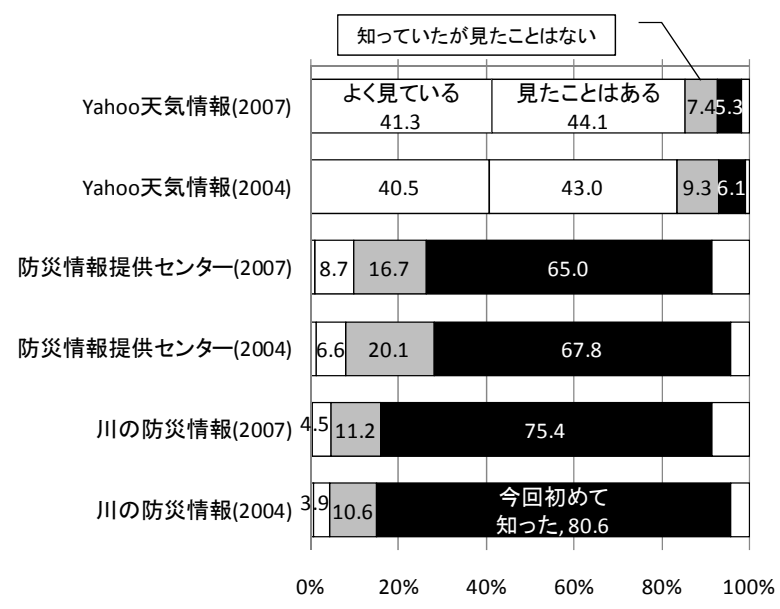

図-3リアルタイム水文情報webl対する認知

一定の回答数に達したところで締め切る方法で行われる このような調査では, 回答者がほぼインターネットの日 常的利用者であることなどから，郵送調查など既存の社 会調査に比へ，回答者の属性に偏りが生じやすいことが 知られている ${ }^{4}$. 今回の調査では, インターネットに比 較的習熟している利用者層の傾向を把握することを目的 としているので, 大きな問題にはならないと考えられる が，念のため，回答者属性の特性について後述するよう にいくつか示している. また，今後，被災地での全数調 查の結果などとの比較検証も進めたいと考えている.

依頼メールは，2007年2月28日配信，3月1日締切で， 有効回答数は528件であった. 一部の設問については, 同様な手法での調査を2004年3月17日〜18日にも実施し
ており, 有効回答数 407 件を得ている. 以下, 前者を 「2007年調査」, 後者を「2004年調査」と呼ぶ.なお, 両調査の回答者は異なっており, パネル調査ではない. また，選択回答は全て回答を記入しないと次のページに 進めない仕様にしており，「無回答」は存在しない.

\section{3. 調査結果}

\section{（1）回答者の属性}

回答者の年代は，30代が最も多く，以下，40代，20代 の順で，20代〜40代でほぼ9割を占めている(図-1)。200 5 年国勢調査の全国総人口と比べると青壮年層に偏った 年代構成になっている．2004年調査と比べると，2007年 調査では20代の比率が下がり，40代の比率が減少し，回 答者の年齢がやや上がっている．性別で見ると，2007年 調査では，男性 $46.0 \%$ ，女性 $54.0 \%$ と，国勢調査(同48.8\%, $51.2 \%)$ と大きな差はない. 2004年調査は同 $40.8 \% ， 59.2 \%$ と，女性の割合が多くなっている。

1週間あたりのインターネット利用時間を尋ねたとこ ろ，2007年調查では 1 時間未満が1. 1\%，1時間以上 10 時間 未満 $45.1 \%$ ，10時間以上 $53.8 \%$ などとなり，ほとんどが日 常的にインターネットを利用している回答者と見られる. また，2004年調査と2007年調查では，利用時間の回答に はほとんど差が見られなかった。

\section{（2）豪雨災害に対する危険性の認識}

自宅の自然災害に対寸る危険性に対寸る認識を尋ねた 結果が図-2である. 浸水(大雨の際の浸水による被害の 発生)に対しては，「危険」および「ある程度危険」が1 5.6\%，土砂災害に対しては同9.1\%で，いずれも1割前後 にとどまる．この傾向は，2004年調査とほとんど変わら ない，世論調査での同様な設問では，水害に対して「危 険」および「ある程度危険」が16.3\%などの結果が出て

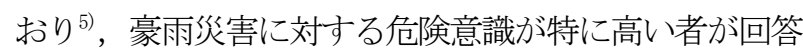
しているといったことはなさそうである.

\section{（3）リアルタイム雨量情報webの認知}

リアルタイム雨量, 水位情報を提供しているWebをい くつか挙げ，それらを認知しているかどうかを尋ねた結 果が図-3である，なお，いずれの質問でも，回答欄の脇 に該当するwebへのリンクを張って，質問しているwebを 実際に確認することができるようにしてあり，名称だけ を挙げて回答を求めているものではない.

2007年調査では，「Yahoo天気情報」は85.4\%が「よく 見ている」または「見たことがある」（以下，この 2 回 答を合わせて「認知率」と呼ぶ) と回答している。 しか し，より詳細な雨量，水位情報を提供している「防災情 報提供センター」(国土交通省) は認知率9. $8 \%$ ，「川の防 災情報」(国土交通省) は同4.7\%で，「存在は知っていた 


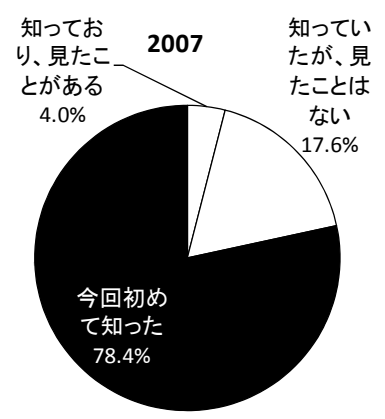

図-4＼cjkstart水位情報が公開されていることの認知
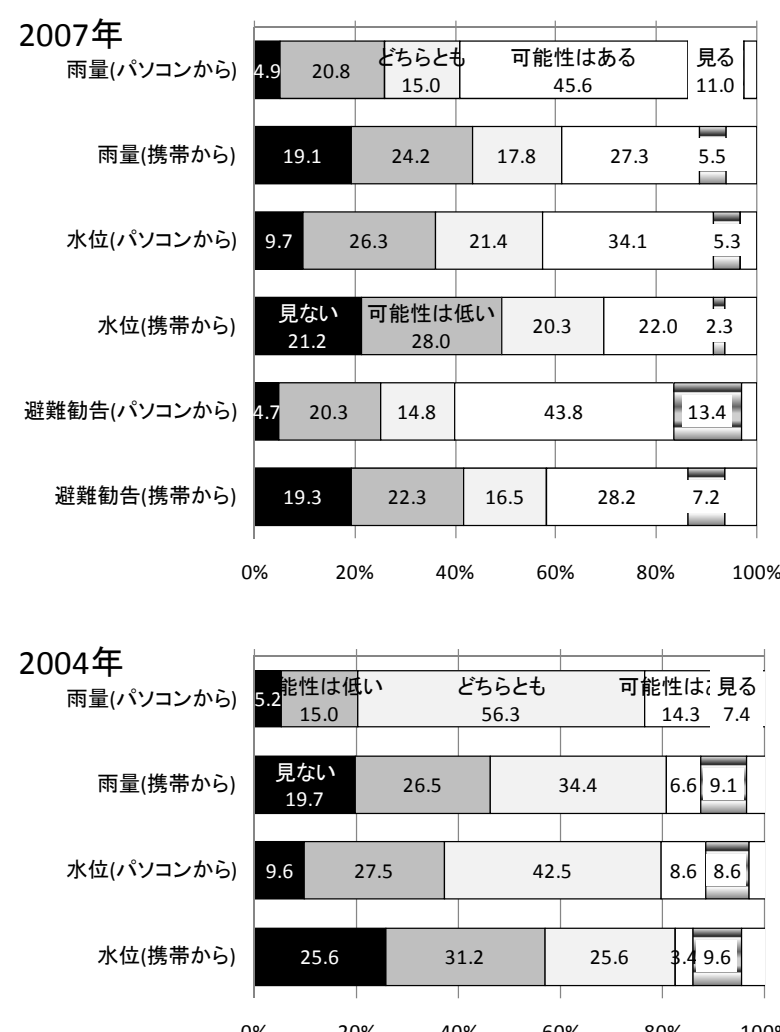

図-5 リアルタイム雨量情報等の災害時利用意向

が見たことはない」と「今回のアンケートで初めてその 存在を知った」という回答が圧倒的多数である.いずれ も2004年調査と比べ，認知率にほとんど違いは見られな い.「川の防災情報」がほぼ現在の姿に整備されたのが 2001年，「防災情報提供センター」の開設が2003年であ り，インターネット上のサービスとしては，すでに開設 から十分な時間が経過している. 開設から日が浅いため に認知が進んでいない状況とは思えない.

更に具体的な質問として，「川の防災情報では全国各 地の河川の水位の情報が公開されています。このことを ご存じでしたか」と尋ねた結果が図-4である.2007年調 查では，「今回のアンケートで初めてその存在を知っ た」が $78.4 \%$ ，大多数は河川の水位が公開されている ことを認知していなかった. 2004年調査では同87.7\%で
あったので，若干認知率は上がったが，「知っており見 たことがある」は2007年4.0\%，2004年3.7\%であり，実際 に利用した回答者は変化していない.

\section{（4）リアルタイム雨量情報等の利用意向}

図-3，図-4で挙げた質問に回答することを通じて，本 調査の回答者は, 「リアルタイム雨量・水位情報や, 避 難勧告・避難指示などの情報がインターネットサイトや 携帯電話サイトで公開されている」という現状自体は認 知したと考えられる. そこで，次に，「大雨による災害 が起こりそうな時に、パソコンや携帯電話から、それぞ れの情報を実際に見て参考にすると思いますか」と尋ね た結果が図-5である.

2007年調査では，「一般の天気予報で伝えられるより はるかに多くの観測地点における雨量(パソコンから)」 については，「確実に見る」および「見る可能性はあ る」が合わせて56.6\%，「市町村ホームページに掲示さ れる避難勧告などの情報(パソコンから)」が57.2\%と， 利用意向がある事を示寸回答が過半数に達した. 「全国 各地の河川の水位(パソコンから)」は $39.4 \%$, 水位情 報に対しては利用意向がやや低くなった，ただし，いず れの情報についても「見る可能性はある」が多くを占め ており，「確実に見る」という強い利用意向を示寸回答 は, 多くても1割程度である.

この設問については，2007年調査と2004年調査の間に 差が見られ，「確実に見る」および「見る可能性はあ る」の比率が，いずれの情報についても2007年調査の方 が高くなった(避難勧告についての設問は2004年調査で は行っていない)。ただし，この変化は，いずれの情報 について見ても，「どちらとも言えない」が減少し，

「見る可能性はある」が増加したことによってもたらさ れた結果であり，「確実に見る」という強い利用意向を 示寸回答には大きな変化が見られない. また，「見る可 能性は低い」，「確実に見ない」という否定的な利用意 向を示寸回答の比率にも，大きな変化が見られない.

2004年調査に対して，2007年調査で，リアルタイム雨 量情報等の利用意向を示寸回答が増加したとはいえ，そ れでも利用意向を示寸回答は半数程度である. また，そ の多くは「可能性はある」という消極的な利用意向であ る. 寸なわち，このような情報の存在が，仮に完全に周 知されたとしても, 災害時に実際に参照する利用者は多 数派にはならないと考えるべきではなからうか.

2007年調査，2004年調査の全ての情報において，同じ 種類の情報に対する「パソコンから」の利用と「携帯電 話から」の利用では，「携帯電話から」の方が，「見る 可能性は低い」および「確実に見ない」という否定的な 利用意向が多くなっている. 携帯電話からの利用意向に ついては，年齢の若い回答者の方が，利用意向がやや高 い傾向が見られたが，その差はそれほど顕著ではない． 図-6に, 雨量と避難勧告の携帯電話からの参照意向につ 

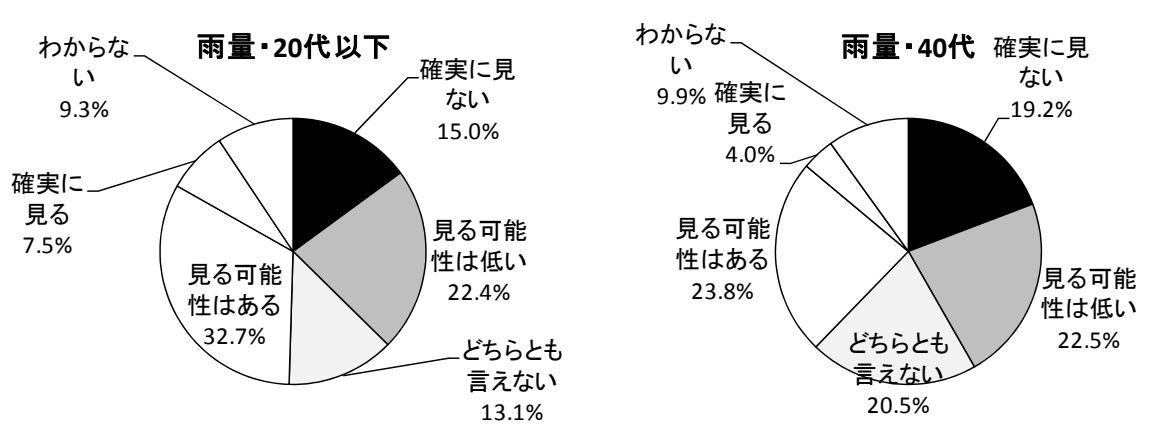

図-6 年代別携帯電話からのリアルタイム雨量情報利用意向
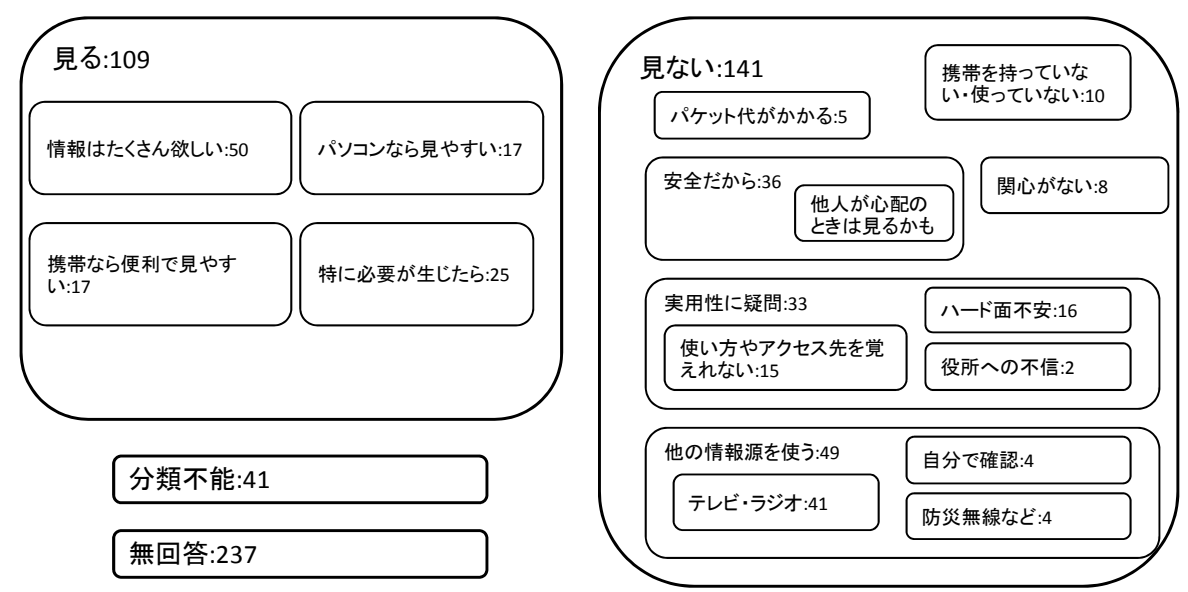

図-7 自由回答の内容分類親和図

いての 20 代以下 (100人) と 40 代 (151人)の回答を示す. 20 代以下では40代と比へ，「見る可能性はある」がやや増 え，「どちらとも言えない」がやや減っている。しかし， 「確実に見ない」及び「見る可能性は低い」という否定 的な利用意向の比率はほとんど変わらない. 携帯電話の 利用場面を選ばず，災害情報提供手段として有利と，情 報提供者側は考えがちであるが，そのように考える利用 者は，年代にかかわらず多くないことが示唆された.

\section{（5）リアルタイム情報に対する考え方 (自由回答)}

2007年調査では，リアルタイム雨量情報等の災害時利 用意向を尋㸚た上で，利用意向のあるなしにかかわらず， その理由を自由回答で記入を求めた. 何らかの回答を記 入した回答者が291人，無回答が 237 人だった.

回答文字数の指定は行なっていないが，最長で155文 字，99\%は100文字未満だった. 内容的に簡潔なものが多 かったため， 1 回答者の回答を1枚のカードとし，共著 者3名によって内容をKJ法で分類した(図-7). 図中の数 字はカード数であるが, 複数の内容が含まれるカードや, 中間的な書き方をしているカードも多いので，カード数 の絶対值についてはあまり厳密な議論はできない.

大別すると「見る」理由と「見ない」理由に分けられ， 「見ない」理由を上げたカードがやや多かった. 見る理 由としては，「住んでいることころの詳しい情報が得ら れるのが良い」など, 詳しい情報, 多数の情報が欲しい,
という理由を挙げる回答が最も多かった.また，「イン ターネットでの情報入手は他の物より簡単だから」や, 「非常時はパソコンをわざわざひらくより携帯から手軽 に見れるほうで見ると思う」など，パソコンや携帯の利 便性を挙げる回答も多く見られた。 また，「余程の大雨 で危険を感じれば、情報収集のために見ると思う」など， 状況によっては見るという趣旨の回答も多かった.

見ない理由は，見る理由に比心゙パターンが分かれた. 最も多かったのは，他の情報源を利用するから，という ものであり，そのほとんどは「テレビのニュースの方が 手軽なのでそちらを見てしまうと思う」など，テレビを 挙げた. また, 自身の被災の可能性が低いことを理由に 挙げる回答も少なくなかった，調査票では，情報を利用 する場面を特に限定して聞いていないが，「自分のとこ ろは高い位置にあって大雨や土砂崩れとは無縁と思って いるのであんまり見ないとは思う」など，自宅にいる場 合の情報利用が主にイメージされたのかもしれない．

インターネットや携帯というシステムの実用性への疑 問を挙げる回答も多かった. このタイプの回答では,

「緊急の場合、パソコンをのんびり見ていると思えない から」や「普段見ないので、いざという時思い出すかど うかわからない」など，利用者の置かれる状況や意識な どのいわばソフト的な理由を挙げるものと，「停電のお それがある場合まったく無意味」や「その時になって、 携帯から見るとなると、込々合ってつながらなそう」な 
表-1 自由回答文の頻出語上位30位

\begin{tabular}{|c|r|c|r|c|r|}
\hline 単語 & 度数 & 単語 & 度数 & 単語 & 度数 \\
\hline 情報 & 90 & 状況 & 16 & 確認 & 10 \\
\hline 携帯 & 63 & 余裕 & 15 & やすい & 9 \\
\hline ない & 63 & 可能 & 14 & 気 & 9 \\
\hline テレビ & 55 & 自宅 & 14 & 場所 & 8 \\
\hline パソコン & 44 & 電話 & 14 & 身近 & 8 \\
\hline 災害 & 37 & ラジオ & 14 & 被害 & 8 \\
\hline 自分 & 21 & 川 & 13 & 良い & 8 \\
\hline 危険 & 19 & 無い & 13 & 安全 & 8 \\
\hline 地域 & 17 & 心配 & 12 & 状態 & 8 \\
\hline 河川 & 17 & 利用 & 11 & ニュース & 8 \\
\hline 必要 & 17 & 早い & 11 & & \\
\hline 大雨 & 16 & 避難 & 10 & 総計 & 1243 \\
\hline
\end{tabular}

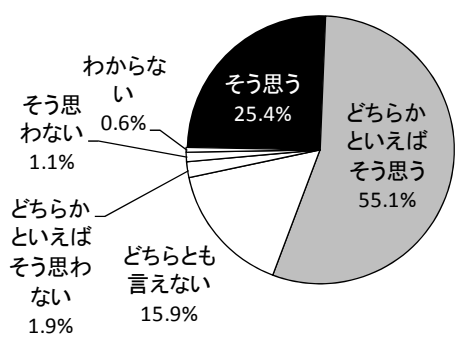

図-8空振りになっても早めに避難勧告を出すべきか

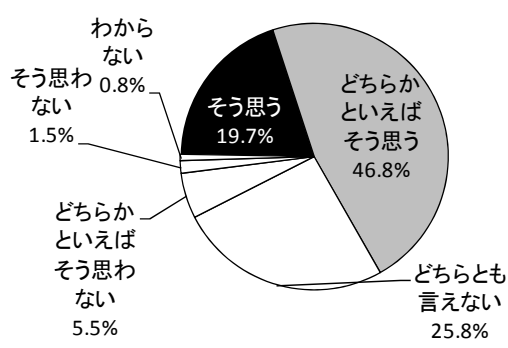

図-9＼cjkstart避難勧告を待たず自主避難すべきか

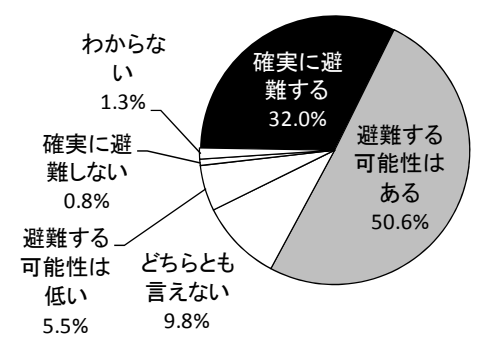

図-10 避難勧告発令時の行動意向

ど，ハード面の不安を挙げる回答が見られた.

自由回答文中の頻出語を調べるため, 奈良先端科学技 術大学院大学が配布している, 形態素解析ソフトウェア

「茶鉒」をもちいて，形態素解析を行った．形態素とは, 動詞, 名詞, 助詞といった, 語の中で変化しない最小単 位のことであり，形態素解析とは，文を形態素に分解す る作業を指す. 解析された形態素(単語)のうち, 名詞及
び形容詞で，出現頻度の上位30位(同順があるため34語) までの単語を表-1に示す。上位に見られる，「情報」，

「携帯」，「パソコン」，「災害」などは，いずれも調 査票の中でも多数使用されている語であり, 頻出するこ とは当然と思われる語である. 一方「テレビ」は調査票 では触れていない語であるが，55件出現した。「テレ ビ」の語を用いた回答のほとんどは，「テレビで情報を 得るから」など，webや携帯よりテレビの利便性が高い という趣旨の回答であり，テレビに対する否定的な意見 は2件だった.「テレビ」を複数使用した回答はなかっ たので, 自由回答記入者の約2割(全回答者の約1割)は, 特に示唆しなくても，豪雨時の情報はまずテレビを利用 することをイメージしたと思われる. 災害時の情報源と してはラジオが強調されるが，「ラジオ」の出現頻度は 「テレビ」の1/4程度の14件(12回答者)だった。

webなどのリアルタイム防災情報の，テレビ等既存情 報伝達手段に対するメリットとしては，詳しい情報が得 られること，伝達時間が短いことなどが考えられるが， この特徴に対応する語は多くない.「早い」，「やす いなどの形容詞がこれらの特徴を表しているようにも 思われるが，「早い」(11件)のうち4件は, webや携帯に 比べテレビなどの情報が「早い」と言つているものであ る.「やすい」のほとんどは携帯とパソコンを比べてど ちらかが「見やすい」と言っているもので，携帯やweb 自体が「見やすい」とする回答は3件に過ぎない.「詳 しい」という語は4件にとどまった.

\section{（6）避難勧告に対する認識}

2007年調査では，雨量・水位情報などより直接的な防 災情報である「避難勧告・避難指示」について回答者の 考え方を尋ねた。 まず，「大雨による災害の可能性があ る場合には、たとえ空振りとなってもよいので、市町村 は避難勧告を早めに出すべきだと思いますか」と尋ねた 結果が, 図-8である.「そう思う」と「どちらかと言え ばそう思う」を合わせると $80.5 \%$ となる. この結果を見 る限りでは, 大多数の回答者が早めの避難勧告を出すこ とを望んでおり，「空振り」を許容せず，慎重な避難勧 告を望む意見はごく少数と見なせる.

また，「大雨による災害の可能性がある場合には、行 政からの避難勧告を待たず、住民が自らの判断で早めに 避難を開始するべきだと思いますか」に対しても，「そ う思う」と「どちらかと言えばそう思う」が $66.5 \%$ と多 数派であり (図-9), 積極的な自主避難に対する肯定的な 意見が多い.ただし，早期の避難勧告よりは肯定的な意 見が少なくなっており, 避難勧告といら情報に対して期 待が寄せられていることがうかがえる.

筆者は本調査と同時期の2006年12月～2007年1月に, 2006年10月の低気圧豪雨災害による被災地(北海道北見 市，佐呂間町，別海町，岩手県葛巻町）で住民対象調査 $\left.{ }^{6}\right)$ を行っており, その中で避難勧告に関して2007年調査と 
同様な質問をしている. その結果，早期の避難勧告につ いては「そう思う」と「どちらかと言えばそう思う」が 78. 7\%，自主避難に関しては，「そう思う」と「どちら かと言えばそう思う」が68.1\%となり，2007年調査とほ とんど変わらない結果となった. 寸なわち, 早期の避難 勧告を望む意見が大多数であること，自主避難に対寸る 肯定的な意見が多数派であることは，直近に災害を経験 した回答者においても同様に見られる傾向であった.

これらの意向は，「空振りを容認するか」と「避難勧 告は早いほうがよいか」に質問を分けるなど，質問の仕 方によっては傾向が変化する可能性があるが, 早期の避 難勧告や自主避難自体に対して否定的な意向を持つ回答 者が少数であることは確かだと思われる. 避難勧告の

「空振り」に対して反発を受けることを懸念して，早期 の避難勧告を出すことに慎重となるといった話を，災害 後の調查などで聞くことがあるが, Silent Majority は 早期の避難勧告を望んでいるのではなからうか.

回答者自身の行動意向について，「あなたが自宅にい た際に、自宅付近で大雨による災害の可能性が生じ、市 町村から避難勧告が出された場合、あなた自身は実際に 避難すると思いますか」と尋ねた結果が図-10である.

「避難する可能性がある」まで含めると80\%以上の回答 者が避難倠告発令時に避蜼する意向を持っていることに なる. 近年の事例でも, 避難率が20〜30\%程度になるこ とがあるので7，「確実に避難する」の回答が特に多す ぎるとは思えない，ただ，「避難する可能性はある」が ほぼ半数に達していることから, 単に避難勧告を「確実 に伝達」するだけでは多くの人が避難するとは限らない こともうかがえる.「避難する可能性はある」と考える 人たちが，避難の必要性を納得できるかどうかで，全体 の避難率が大きく変わってくるものと思われる.

\section{4. おわりに}

住民一の情報提供を目的として, web等の整備が進ん でいるが, 整備から3年以上が経過した「川の防災情 報」などの認知率は1割に満たず，この3年間でもほとん ど変化していないことが分かった．また，これらのweb を具体的に紹介した上で今後の利用意向を尋ねても，積 極的な利用意向を示寸回答は1割前後だった.リアルタ イム防災情報の存在を周知徹底しても，災害時にそれを 利用する人は多数派にはならない可能性は以前も指摘し たが”，今回の結果を踏まえると，ほぼ確実と言ってい い. リアルタイム防災情報を利用しない理由としては, 災害の危険があるような場合に，パソコンや携帯電話を 利用して情報収集することは現実的でなく, テレビなど 他の情報媒体の方が便利であることなどが挙げられた.

すなわち, 内容的に充実したリアルタイム防災情報 web (携帯も含む)を整備しても，その存在の周知には限
界があり, 周知しても, 誰もがそれを利用する状況は, 今後もあまり期待できそうにない，今回の調査は，イン ターネットに習熟した利用者を対象とした結果であり, インターネットに習熟していない人の存在を考えると, 状況は更に厳しいであろう。

避難勧告に対する考え方などの回答を見ると，早期の 避難そのものに対して否定的・消極的な回答者は少ない ものの, 避難勧告を伝達しさえすれば大多数の人が避難 するということは期待できそうにない.

「豪雨災害時に詳しい情報が欲しい」というニーズが あること自体は確かであるが，自ら能動的，積極的に情 報を収集したいという意向を持っている人はけして多く ない，webを中心とした詳細な防災情報は，不特定多数 が使う事を期待するものではなく，防災関係者など，状 況判断が必要な人に特に利用してもらう必要性が高い情 報と位置づけるべきであろう. 不特定多数に対する情報 としては，ITC系技術にこだわらず，能動的な情報収集 の努力を求めない, より単純な情報と伝達手段も考える べきではなからうか. 一例としては, 高価な防災無線の 「各戸受信機」ではない「防災無線が聞けるラジオ」な どはかなり現実的である。防災情報は整備して利用を待 つのではなく，その情報を，誰がどのように使うのかに ついての計画, 提案がさらに必要である.

なお，本研究の一部は，2007年11月の日本災害情報学 会第9回研究発表大会で口頭発表したものである.

謝辞 : ご回答いただいたgooリサーチモニター各位に感 謝申し上げる. 本研究の一部は, 京都大学防災研究所一 般共同研究，平成19年度科学研究費補助金「災害情報に よる人的被害軽減効果に関寸る研究(研究代表者 牛山 素行)」の研究助成によるものである.

\section{参考文献}

1) 気象庁: 防災気象情報の満足度に関寸る調查報告書, 2005.

2) 村上啓介, 杉尾哲 : 平成17年台風14号時の住民の避難行動之 防災意識について，災害情報，No.5，pp.67-75，2007.

3) 牛山素行, 今村文彦, 片田敏孝, 吉田健一: 高度防災情報時 代における豪雨災害時の住民行動，水文・水資源学会誌，

Vol.17, No.2, pp.150-158, 2004.

4) 大隅昇, 吉村宰編 : 調査環境の変化に対応した新たな調查法 の研究(CD-ROM), 2004.

5) 内閣府 : 水害・土砂災害等に関寸る世論調査, http://www8.c ao.go.jp/survey/h17/h17-suigai/index.html, 2005.

6) 気象庁札幌管区気象台ほか：2006年10月6日～9日の発達した 低気圧による災害に関するアンケート調查報告書, http://ww w.sapporo-jma.go.jp/topix/houkoku19/houkoku1910/houkokukai/h oukokusyo.pdf, 2007.

7) 竹内裕希子 : 水害時の住民の降雨認識と避難行動, 防災科学 技術研究所主要災害調查，No.40，pp.103-110,2006.

(2007. 9. 30受付) 